\title{
Sustainable Livelihood Strategies of the Riverine Communities at Sadong Jaya, Sarawak, Malaysia: Role of Capital Assets
}

\author{
SU JIN TAN, SWEE KIONG WONG*, REGINA GARAI ABDULLAH \\ Faculty of Social Sciences and Humanities, UNIVERSITI MALAYSIA SARAWAK, MALAYSIA \\ E-mail: swkwong@unimas.my
}

\begin{abstract}
The aim of this paper is to explore the role of capital assets in sustaining the livelihoods of the riverine communities with special focus on physical and human capitals. The study was carried out at Sadong Jaya, a subdistrict under Asajaya District, Samarahan, Sarawak. It is located at the lower Sadong River lying in the Southwest of Sarawak in the Borneo Island. Due to the dynamic nature of the local environment with its unique geographical location prone to flash flood and monsoon flood, it is crucial to examine the role of physical and human capitals in affecting livelihood strategies adopted by the local communities. A mixed method approach encompassing exploratory study and descriptive analysis was adopted. Multistage sampling techniques were used to select 11 villages along the lower estuarine, middle estuarine and upper estuarine areas, followed by systematic sampling technique employed to select 243 heads of households for face-to-face interviews to find out their livelihood strategies and vulnerabilities faced by them. Data collection involved observation techniques, two FGDs and indepth interviews with various stakeholders. The findings show that riverine communities at Sadong Jaya utilize diversified livelihood strategies by optimizing the use of capital assets available to sustain their livelihoods. Communities who are better equipped with an enhanced and diversified assets base are more resilient. The study found that infrastructures such as roads and bridges, water supply, drainage systems, watergates and education facilities enable the riverine communities to intensify and diversify economic activities, widen job opportunities and market opportunities. As accessibility to education and training facilities is made available to the locals through better connectivity facilitated by various physical infrastructure, more riverine communities are involved in non-agricultural economic activities and out-migrating to cities and abroad. The paper concludes that provision of basic physical and educational amenities is crucially imperative as a policy recommendation to ensure that the riverine communities are able to enhance their livelihoods strategies for uplifting their standards of living.
\end{abstract}

Keywords: Livelihood assets, riverine communities, sustainable livelihood, vulnerability, Sarawak

JEL Classification: C1, L2 


\section{Introduction}

In pursuant to achieving Sustainable Development Goals (SDGs) by 2030, sustaining livelihoods has become one of the important elements to ensure no one is left behind in the development agenda. Livelihoods is a multi-dimensional and complex issue (Bebbington, 1999; DeHann, 2012; Ellis, 1998). Masud et al. (2016) describes livelihood as a mean of living far beyond the notion of simply having a job for earning a living. A livelihood encompasses not only income, social relations and property rights, but also access to, and benefits derived from social and public services such as water supplies, education and health services (Ellis, 1998). In other words, a livelihood is a "combination of assets (natural, human, physical, financial and social capital), activities and access to these (mediated by institutions and social relations) that together determine how an individual or a household make a living" (Ellis, 2000, p.10). Livelihoods are also subject to shocks and changes, particularly when the communities are heavily dependent on the access to natural resources. The level of access to resources or capital assets influences the level of resilience of the local communities and it determines how well they react to changes. Riverine communities are examples of communities that heavily rely on natural resources. The riverine communities refer to communities who live along a river basin and where majority of the people practice and sustain their livelihoods with water related activities (Oriola \& Chibuike, 2016). This includes fishing activities in the river and agriculture activities on floodplains.

Having spatial and geographical disparities compounded with diversity in resource endowment, each community would develop diverse livelihood strategies to cope with different shocks and stresses imposed to them. This paper is part of a larger study which examines the roles of capital assets, particularly in terms of physical and human assets ${ }^{1}$ using the theory of access and resilience theory. Both theories are discussed in the context of sustainable livelihoods. The sustainable livelihood approach builds upon the communities' definitions of opportunities and constraints while paying close attention to the institutional policies affecting their livelihoods. Thus, the aim of this paper is to highlight how a riverine community of Sadong Jaya, Sarawak, Malaysia, addresses their livelihood options and challenges, specifically in the context of their response to physical and human assets they own and socio-political and environmental conditions that they face.

\subsection{Background of the Riverine Communities in Sadong Jaya}

Figure 1 shows the map of Sadong Jaya, Sarawak, Malaysia. Sadong Jaya $(1.513439,110.738991)$ shares the coast of South China Sea and is located at the lower Sadong River. This river, which stretches about 72 kilometres in Western Sarawak, serves as an important source of livelihood, a transportation medium, water source for irrigating agricultural land, and source of drinking water and livelihood activities for the local riverine communities. Sadong Jaya is unique as it is situated at an estuary having a dynamic ecosystem where the flow of water consists of tides from freshwater and seawater (Chen, Kao \& Chiang, 2013). The estuary areas are where most pressured ecosystems face urban and industrial runoff from inland areas that carry along rivers into estuaries (Chen et al., 2013) and environmental degradation from anthropogenic activities and climate change (Miththapala, 2013; Elliot et al., 2014).

The Sadong Jaya riverine community comprises of 25 villages with a total population of 14,937 people (Sadong Jaya Sub-District Office, 2019). The population are ethnically diverse, with a majority of them Malay, Iban and Chinese at $79.45 \%, 6.58 \%$ and $6.48 \%$ respectively while other ethnicities such as Bugese, Jawanese, Melanau, Bidayuh and Indian households comprises of $7.50 \%$ of the total population in Sadong Jaya (Sadong Jaya Sub-District Office, 2018). Its location on a floodplain causes the area to experience annual flooding due to concurrent existence of king tides and heavy rainfall. The latter usually occurs between November and March during the monsoon season every year.

\footnotetext{
${ }^{1}$ In this study, physical and human assets are treated the same as physical and human capitals and they are used interchangeably.
} 
Figure 1 Map of Sadong Jaya, Sarawak, Malaysia.

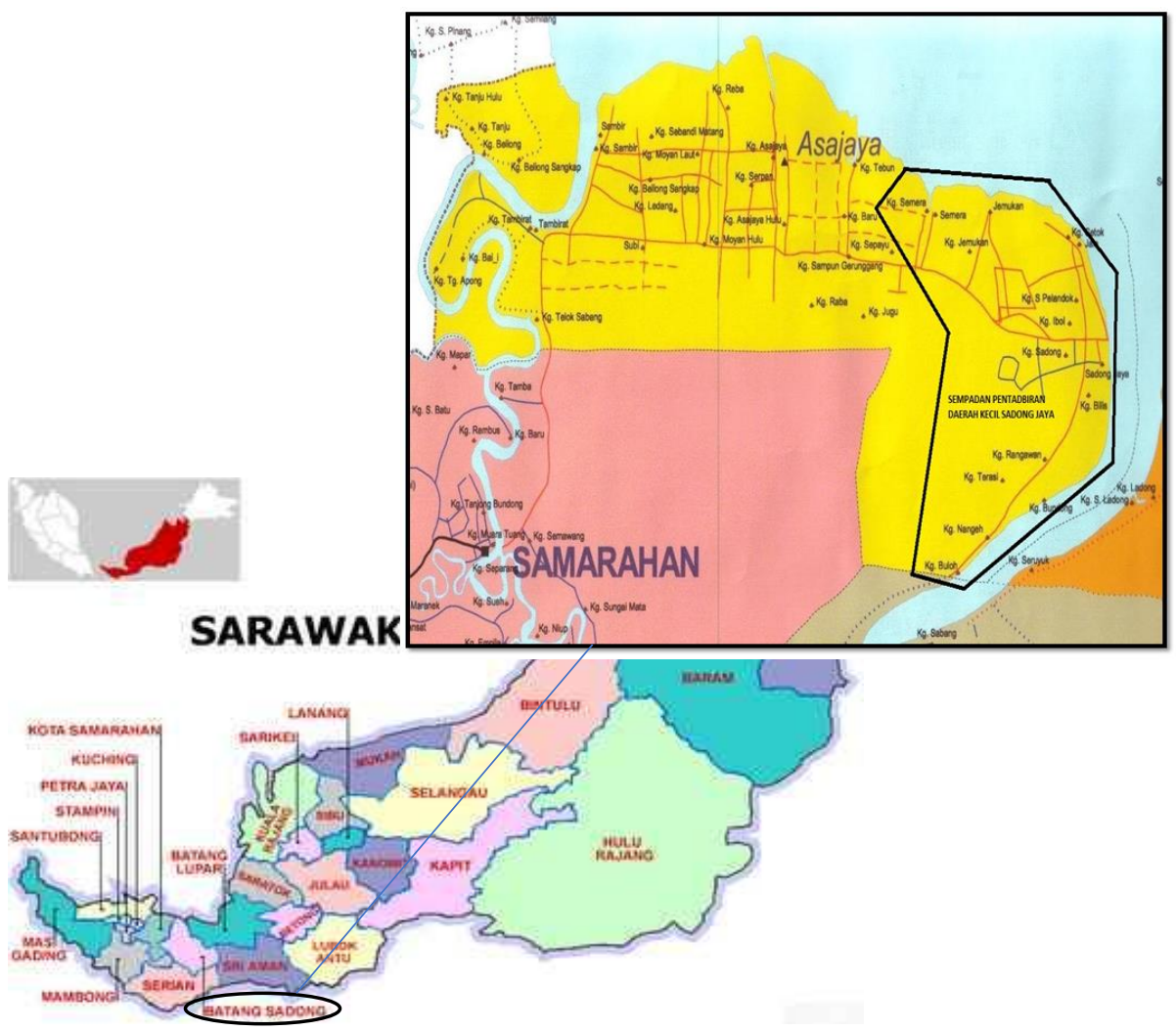

The main economic activities at Sadong Jaya include agricultural activities, aquaculture, animal husbandry and small-medium enterprises (SMEs). Many also work as labourers in construction, manufacturing, and service industries either within the same area or as daily commuters to seek employment opportunities in nearby town and city like Kuching. Understanding the dynamics of the livelihood systems by the resource-dependent communities, such as Sadong Jaya, is significant. It allows for the identification of the limitations and strengths of the community and its surrounding and, consequently, enabling policy makers to devise appropriate policies and implement relevant strategies to improve the welfare of the local community, at both household and community levels.

It should be noted that Sadong Jaya had experienced dramatic physical development in the last four decades since 1980s. This physical development refers to the physical assets consisting of infrastructures or ownerships needed to support livelihoods (Scoones, 1998). They include the availability of, and accessibility to roads, affordable modes of transportations, water supply and equipment used for economic activities. In fact, many basic amenities and public infrastructure such as roads connecting one village to another, bridges, watergates, and more proper drainage systems were constructed in Sadong Jaya over the last four decades. Table 1 summarizes the chronological order of major physical infrastructure development that took place in Sadong Jaya since the 1980s.

Among some significant infrastructure development in Sadong Jaya include a major shift from river transportation to road transportation system. For example, the riverine communities in Sadong Jaya relied on the river for transportation using sampan and motorboats for many years. In 1996, express boats which can accommodate 40-70 passengers were still vastly used to travel to towns. However, these express boats were highly dependent on the tides. Each change of tides approximately takes six hours which were sometimes irregular. The limited time gap and small capacity of express boat caused a longer waiting time for the riverine communities to travel to cities, especially during harvest seasons when riverine communities transported their harvest to the city to sell. In year 2000, tar-sealed roads were built and extended into farmlands by stages. Since then, the riverine communities in Sadong Jaya used road transportation to substitute river transportation to access to various public and social amenities, markets for goods and services including the job market. They abandoned river as their 
means of transportation in 2018 when Samarahan Bridge was completed. The reason is that it is relatively cheaper and more convenient to access to various services at nearby towns anytime they want by roads. These infrastructures or improvements of these physical assets have in fact reshaped and improved livelihoods of the riverine communities in Sadong Jaya.

Table 1 Summary of Major Physical Development Taking Place in Sadong Jaya since 1980s.

\begin{tabular}{|c|c|}
\hline Year & Physical Development \\
\hline 1980s & Roads were built connecting one village to another village \\
\hline 1986 & $\begin{array}{l}\text { Watergates construction at: - } \\
\text { - } \quad \text { Kampung Semera } \\
\text { - } \quad \text { Kampung Jemukan } \\
\text { - } \quad \text { Kampung Pelanduk } \\
\text { - } \quad \text { Kampung Jaie }\end{array}$ \\
\hline 1990 & $\begin{array}{ll}\text { Watergates construction at: - } \\
\text { - } & \text { Kampung Sungai Bilis } \\
\text { - } & \text { Kampung Sungai Putin } \\
\text { - } & \text { Kampung Terasi } \\
\text { - } & \text { Kampung Sungai Buluh }\end{array}$ \\
\hline 1996 & $\begin{array}{l}\text { Express boats used as mode of transportation to nearby } \\
\text { towns (i.e. Samarahan, Kuching) }\end{array}$ \\
\hline 2000 & $\begin{array}{l}\text { Tar-sealed roads were built and further extended into } \\
\text { farmlands }\end{array}$ \\
\hline October 2016 & Completion of Sadong Jaya Bridge \\
\hline June 2018 & Completion of Samarahan Bridge \\
\hline
\end{tabular}

As stated by USAID (2018), communities do not remain the same but often oscillate between enhancing or plummeting over time in terms of their socio-economic status, as well as their access towards different capital assets. It is on this fundamental basic that this study is crucial to fill the literature gaps particularly on the understanding about the availability of resource capitals and its role in enhancing the livelihoods of the communities in Sadong Jaya, Sarawak. In this context, resourcedependent communities have the advantages and would potentially fare significantly better than those communities that do not have the accessibility to the available resources and thus unable to utilise the resources for livelihood enhancement. Livelihood strategies are incorporated depending on the accessibility and capabilities of capital assets a household possess (Yuerlita, Perret \& Shivakoti, 2013).

\section{Literature Review}

The concept of sustainable livelihoods was advanced through the promotion about poverty alleviation and environment protection with the Brundtland Commission Report 1987 (WCED, 1987). DeHaan (2012) emphasizes the need to holistically study livelihoods as it is not just concerning poverty levels, well-being and welfare, but also issues on the quality of space, power relations, climate change, environment degradation, mobility, and migration.

Several sustainable livelihoods studies have been carried out in the past using both qualitative and quantitative approach in different countries such as Ghana (Abukari, 2014), China (Liu et al., 2017) and India (Bhattarcharjee, 2009). Several livelihoods such as the forest-based communities (Ofoegbu et al., 2016), riverine and fishing communities (Efobi \& Anierobi, 2013; Akther et al., 2017) are covered. In Malaysia, scholarly literature is available largely in Peninsular region on poverty eradication and sustainable livelihoods (Kamaruddin \& Samsudin, 2014).

In general, the sustainable livelihood approach focuses on livelihoods that reduces poverty by identifying rural communities' issues and problems using their capital assets (Ashley \& Carney 1999; Chambers \& Conway 1991; Ellis 2000; Scoones 1998). In this context, capital assets refer to "possessions which are material and social, tangible and intangible enabling the people to have the 
ability to pursue different livelihood activities" (Krantz, 2001, p8). The sustainable livelihoods approach identifies five capital assets which form the core dimensions of the framework. These five capitals are crucial in analysing how people endeavour to convert their capabilities into livelihood outcomes. Figure 2 below shows the five capitals in the Sustainable Livelihoods Framework.

Figure 2 Five Capital Assets in the Sustainable Livelihoods Framework

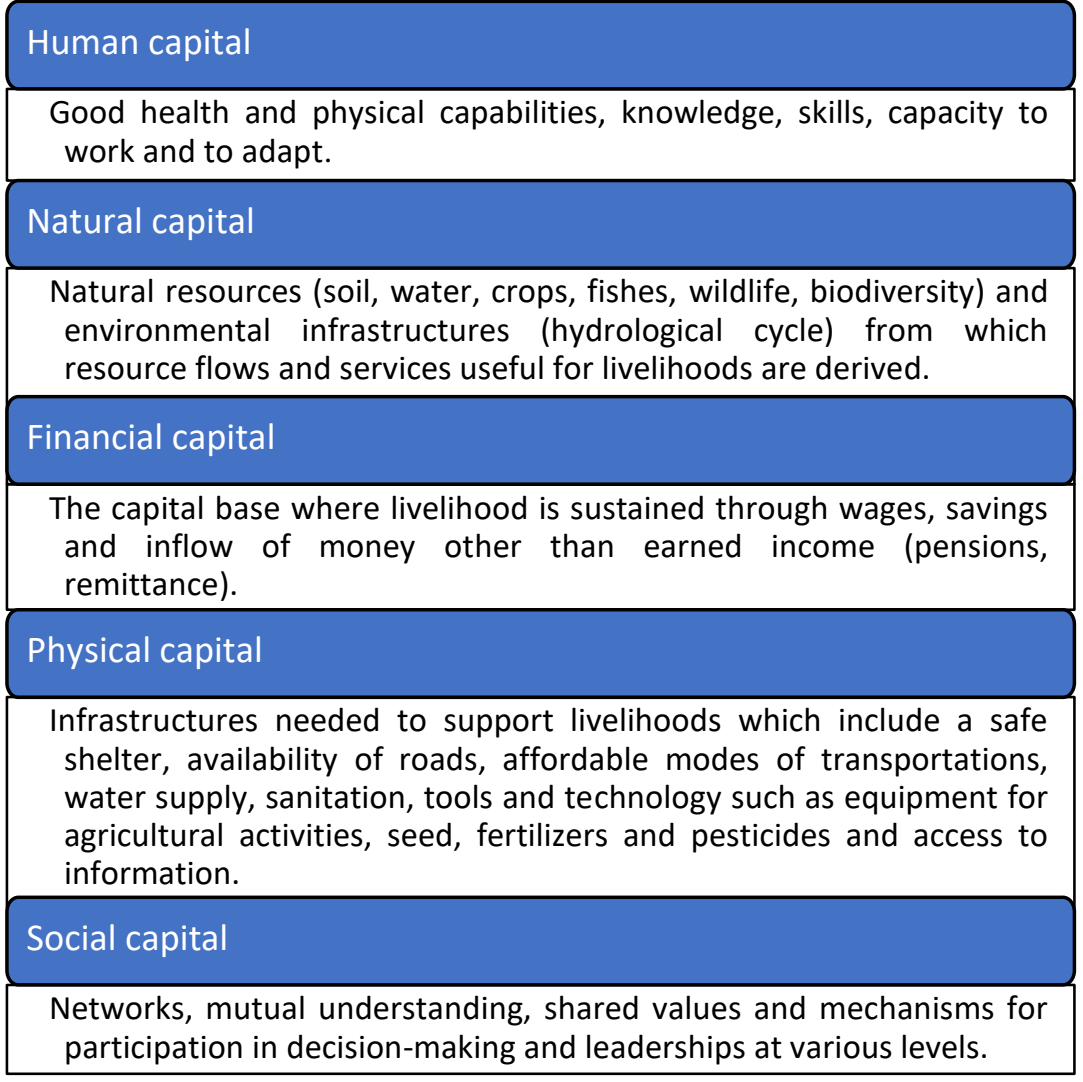

Source: Adapted from Scoones (1998) and UNDP (2017).

In addition, Bebbington (1999) emphasized that assets also include the elements of empowerment and change, and not just resources for building livelihoods. Different levels and access to different ownership of livelihood assets can affect the choice of livelihood strategies and the level of family wellbeing (Ellis, 2000; Yizengaw et al., 2015). Level of access to assets may also be influenced by policies, processes and institutions, which, in turn, shape livelihoods as they operate at many levels, ranging from household to international levels. Civil society organizations, public and private sectors which regulate access to assets, markets, power relations and culture can either strengthen or constrain livelihoods (Daw et al., 2009; Twigg, 2001).

Ribot \& Peluso (2009, p.154) focus on access as the ability to benefit from things (material objects, persons, institutions, and symbols) which is used to analyse "who actually benefits from things and through which processes they are accessed". In their Theory of Access, the focus is on the ability, rather than rights, which brings attention to a wider range of how these resources can enable or constrain people's social relationships. Ribot \& Peluso (2009) point out that access relations within social relationships always change depending on the positions and power held by an individual or a community. Similarly, Scoones (1998) also states that access to resources constantly reshapes people's livelihood portfolios. Meanwhile, Myers \& Hansen (2019), who reviewed the Theory of Access relating to materiality and power, describe 'materiality' as the geographical characteristics in which humans and 'things' are located. Myers \& Hansen (2019) discuss how different actors at different geographical locations are accessible, benefited and constrained to different 'things'.

A livelihood is said to be sustainable if it can cope and recover from stresses and shocks; maintain or enhance its capabilities and assets, while reserving natural resource base (Chambers \& Conway, 1992; Scoones, 1998). It means that those who are able to pull through a disaster without having to 
lose their capital assets and destroy the environment are more liveable compared to those who do not. Additionally, communities that are better equipped with an enhanced and diversified asset base are more resilient (Sharma et al., 2014) and able to survive shocks and reduce livelihood stresses (Chambers \& Conway, 1991). In this context, shocks are effects which are unpredictable, distressing and typically sudden, while stresses are trends which occur in long term, cumulative and predictable (Conway \& Barbier as cited in Chambers \& Conway, 1991).

According to Dlamini (2014), the understanding of the terms resilience and vulnerability has been a subject of concern over the years. The concept of resilience is rooted from sustainable livelihoods and ecology (Schipper \& Langston, 2015). It is on how people respond and adapt to changing stresses and shocks that affect their livelihood outcomes (Manyena, 2006). Vulnerability, according to Adger (2006), is the susceptibility of circumstances during insufficient finance or breakdown in other endowments. Meanwhile, resilience focuses on a more sustainable, long-term adaptation where it is seen as a continuous and on-going process of interaction between the human and natural system as they consistently evaluate information from the past and incorporate values and norms into decision making (Nelson et al., 2014). Nevertheless, numerous entry points of resilience and vulnerability to which any given concept can be tracked back means that contradiction and overlaps in the uses and definitions exist (Schipper \& Langston, 2015).

The sustainable livelihoods of the riverine communities depend on the strengths and weakness of physical and social infrastructures available and accessible to them. The identification of these strengths and weaknesses enables the maintenance of a community welfare. As the efficiency and effectiveness of a household adopting a livelihood strategy is strongly linked to their demographic and socio-economic characteristics (Farzana et al., 2017), the scale of problem-solving may vary from villages to villages, and from households to households.

\section{Methods}

This study employed a mixed method approach focussing on accessibilities of capital assets that affect the livelihoods of the riverine communities in Sadong Jaya. This approach was chosen because of its ability to allow exploration holistically on the nature and the socio-environmental perspectives of different stakeholders. This exploratory study was designed into several stages: field study stage where primary data were collected from various stakeholders, and a document analysis stage where the secondary data were analysed. The latter includes data on distribution of the villages, population size, community livelihoods, infrastructure and facilities, as well as rainfall distribution and other relevant data from relevant institutional organizations such as Fisheries Department, Malaysian Meteorological Department and District Office.

The research site, Sadong Jaya, was first grouped into three clusters based on their geographical locations (Refer Figure 3): lower estuarine, middle estuarine and upper estuarine. Respondents were selected using a multistage sampling method. In the first stage, eleven villages were purposively selected from each cluster: two (Kampung Semera Lot, Kampung Jaie) at lower estuary, four (Kampung Jemukan Cina, Kampung Pelanduk Ulu, Kampung Iboi Ulu, Kampung Sadong Jaya) at middle estuary and five (Kampung Terasi Iban, Kampung Rangawan, Kampung Sungai Putin, Kampung Tanjong Kelaso and Kampung Sungai Buluh) at upper estuary. After selecting the villages, the second stage involved selecting households based on a systematic random sampling method. A total of 243 households from eleven villages were selected for the study. 
Figure 3 Location of the 11 selected villages in Sadong Jaya.

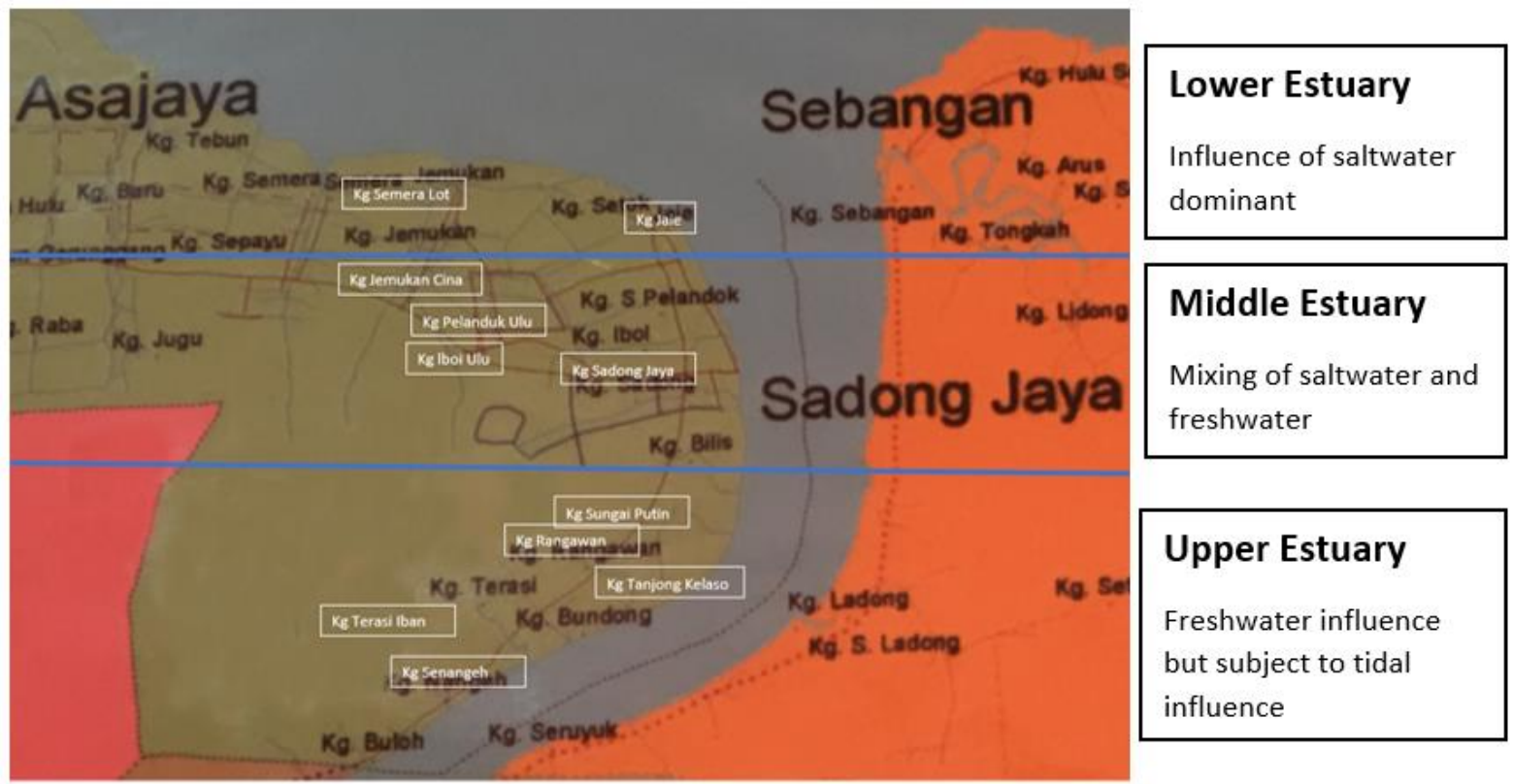

This research was conducted between December 2018 and January 2020. The primary data were collected using interviews, focus group discussions and site observation techniques. Interviews with key informants including the Sub-district officer and community leaders, were carried out particularly in soliciting overall development project, issues and challenges faced in the area. Besides being gatekeepers, the community leaders were chosen as they were the key informants to provide information on general overview of availability and constraints of capital assets and livelihood strategies at local context particularly at their respective villages or administrative boundaries. Focus group discussions based on semi-structured interview schedule were conducted with different groups of the community leaders comprising mainly the headmen, pemanca and penghulu of the villages. This is done mainly to capture information such as the changes of economic activities, changes in physical and human capital structures and types of institutions, structure of community social interaction which may have hindered or improved the livelihoods of the riverine communities. Face to face interviews were carried out among heads of the households or their representative majority of whom are housewives at the household level data collection stage. The socio-demographic information, economic activities adopted by the individual household, types of assistance received, monthly income and expenditure as well as participation of community social interaction were solicited through faceto-face interviews with the heads of the households. In addition, secondary data on frequency of flood occurrence, statistics on rainfalls including average monthly precipitation amount, population size, village profile including livelihoods of the communities at Sadong Jaya, number of social institutions and organizations, infrastructures and facilities available at Sadong Jaya, were also obtained.

All data was then analysed using a narrative and qualitative approach by using content and thematic analysis. Besides that, the descriptive analysis was employed for data acquired from face-to-face interviews on socio-demographic characteristics and accessibility of the capital assets by the local communities to depict the livelihood assets and strategies adopted by the community in terms of sustaining their livelihoods. The latter data was coded and analysed using SPSS version 21.

\section{Results and Discussions}

Demographic information of a household can determine the income generation capacity, and household production and consumption (Elasha et al., 2005). Sadong Jaya is unique with its diverse human population distribution comprising of different ethnic groups. These Sarawakians live together harmoniously at Sadong Jaya with each ethnic group adheres to their own customs and traditions. In this study, a total of 191 (78.6\%) respondents interviewed were Malay, 16 (6.6\%) Iban, 16 (6.6\%) 
Chinese and 20 (8.2\%) other ethnic groups such as Jawanese and Bugese. In fact, this distribution is close to the distribution of population recorded by the Sadong Jaya Sub-district Office in 2018 as reported in the earlier section. From a total of 243 households surveyed, 222 households (91.4\%) are headed by males who are between the ages of 30 and 89 years old.

Table 2 Distribution of the Respondents by Age Group.

\begin{tabular}{|c|c|c|}
\hline Age Group & Frequency & Percentage (\%) \\
\hline Less than 20 & 3 & 1.2 \\
\hline $21-30$ & 33 & 13.6 \\
\hline $31-40$ & 37 & 15.2 \\
\hline $41-50$ & 54 & 22.2 \\
\hline $51-60$ & 66 & 27.2 \\
\hline $61-70$ & 40 & 16.5 \\
\hline $71-80$ & 8 & 3.3 \\
\hline $81-90$ & 2 & 0.8 \\
\hline
\end{tabular}

Table 2 depicts the distribution of respondents involved in this study by age groups. Majority respondents involved in this study were within the age group of between 41 and 60 with a mean age of 48 years old. Most respondents have an education level of between primary and lower secondary school. On average, there are five members in each household. Of the household heads, 32 (13.2\%) did not have any formal education, 85 (34.9\%) attended primary education, 118 (48.6\%) attended secondary education and only eight (6.9\%) managed to attain tertiary education.

About 167 (68.7\%) household heads are semi-skilled, and their skills are gained from the working experience of more than 10 years in their respective fields mostly in farming and fishing activities. Only six respondents mentioned that they have more than 10 years' experience of operating business. Twenty-four respondents (9.9\%) are skilled workers who have attended formal training and obtained certificates mainly working with the public sector. Fourteen respondents (5.8\%) have working experience less than 10 years while $38(15.6 \%)$ heads of the households do not work. The results are consistent with findings of Yassin et al. (2018) indicating that most elder people possess skills through work experience despite lacking in formal education.

According to Luqman et al. (2018), human asset cultivated through education becomes the key role in an individual's human capital development as it influences the capability of an individual to have access to other capital assets. Yassin et al. (2018) also states that human capital appears to be the best asset possessed by rural youth. Human capital encompasses capacities, knowledge, skills, and attributes which influence the earning potential, capacities and productivity of an individual (Khazanah Research Institute, 2018). Thus, the accessibility of the riverine communities to education and training facilities in Sadong Jaya determines their human capital development and subsequently affects their livelihoods. There are a total of 11 primary schools (nine national schools and two Chinese schools) and two secondary schools, and two training facilities (Giatmara Jemukan and Giatmara Batang Sadong) within easy access of the people in Sadong Jaya. Xing (2016) showed that the probability of non-farm job increases when the education level increases.

In terms of participation of family members in workforce, households in Sadong Jaya have between zero and seven family members in the workforce (Refer Figure 4). The findings show that $101(41.6 \%)$ households have a sole breadwinner in their households followed by 135 (55.6\%) households having two or more family members generating income in the workforce. About seven (2.9\%) households do not have any family member participating in the workforce. 
Figure 4 Distribution of Respondents by Number of Household Members Participating in the Workforce

Number of Family Members Participating in Workforce

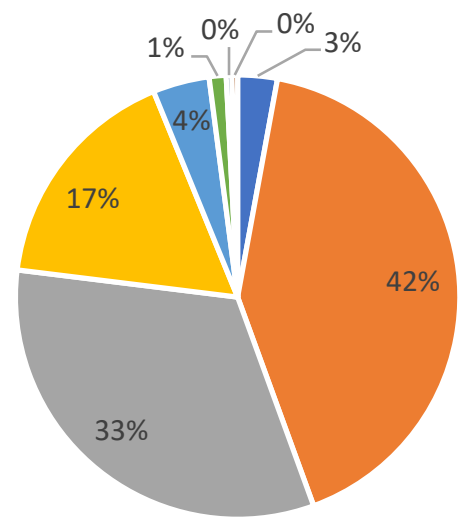

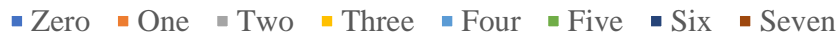

From the interviews carried out with the respondents, it clearly shows that improvement in human assets enhances the livelihood strategies adopted by the riverine communities. For example, out of nine tailors in Sadong Jaya, four tailors have received formal training in vocational or skill training centres. A young unmarried female (26 years old) respondent who received her training from Giatmara and stayed together with her elderly parents at Sadong Jaya shared that:

"After I completed my training at Giatmara, I was given a sewing machine and an embroidery machine worth RM2,500 each to start my business. I started with doing small stitching and clothes but now, especially during the peak period, which is during Hari Raya season, I can take up to 12 orders per week. I also expanded my business on embroideries. My embroidery machine is open sometimes overnight to complete the orders." (Respondent 3, Kampung Jaie, 2019)

The experience of the young tailor from Kampung Jaie at the lower estuary of Sadong River above testified that she was able to support herself without having to financially burden the elderly parents by securing RM500.00 per month by providing tailoring services during normal days after she has enhanced her skills at Giatmara. From being unemployed, she was financially independent after going through the training at Giatmara. She happily reiterated that she could even earn double of her normal monthly income during peak season every Raya Celebration. The reason was that the order for her tailoring service increased during festival seasons. This shows how access to education or training in relevant skills enhances human capital development that subsequently empowers individuals to be able to participate in the workforce. Generally, the riverine communities at Sadong Jaya are able to enhance their livelihood strategies after attending proper human capital enhancement programmes.

Samuel et al. (2017) contemplated that riverine communities with average level of formal education and low-income do not have adequate preparedness or mitigation measures in facing vulnerabilities. Despite high dependency in the natural resources available, the riverine communities at Sadong Jaya cope with these vulnerabilities by diversifying their economic activities to sustain their livelihoods. In general, all households surveyed in Sadong Jaya have between one and five livelihood sources which can provide them with cash income for living. This includes involvement in small and medium enterprises (SMEs), working as labourers in construction, manufacturing, and service industries. Besides that, households in Sadong Jaya also receive remittance from family members or relatives working outside of the village, fixed salary from being government and private sectors staff, and monthly pensions as their sources of livelihoods. Generally, households who diversify their livelihood strategies are better-off in terms of income (de Silva \& Kodithuwakku, 2010; Nathan \& Mohamad, 2014), and shocks and risk adaptation (Gebru, Ichoku \& Phil-Eze, 2018) compared to those who did not do so. This is because diversification provides flexibility to acquire source of income (de Silva \& 
Kodithuwakku, 2010; Hussein \& Nelson, 1998) and to reduce income fluctuation (Haggblade, Hazell \& Reardon, 2010).

The main economic activities carried out in Sadong Jaya is agriculture. A total of 209 households are involved in agriculture, and from this figure, 153 (63.0\%) households are involved in agriculture as they have inherited the land and profession from their ancestors. This indicates that accessibility to natural resource such as land and human capital such as farming skills inherited from ancestors did influence the livelihood strategies adopted by the riverine communities in Sadong Jaya. There are $54(22.2 \%)$ households who are doing agriculture due to their interest and passion. Though majority of the households interviewed were involved in agriculture, only $89(36.6 \%)$ households are getting their main income from agriculture. This implied that agriculture is only part of their livelihood strategies as most have income derived from other source of economic activities such as small business and receiving remittance from family members who are working outside the village. As highlighted by Boncinelli \& Casini (2014), agricultural households have less "material" well-being in terms of cash income and housing, they are better endowed with intangible well-being like health, environment, safety including the social networks. That is why we could see more than $20 \%$ of the households participated in agriculture out of their interest and passion in Batang Sadong to sustain their livelihoods.

In terms of types of agriculture activities participated by the riverine communities, the findings of the study indicated that between 1970s and 1980s, swamp paddy and coconuts were the main agricultural crops at Sadong Jaya. These agricultural crops were gradually replaced by oil palm and other commodity plants, such as maize and bananas which fetched higher market price. Although the main factor of the crop replacement was due to the higher market price, poor drainage system as a result of the construction of watergates also caused some crops such as coconut plantation not able to grow well today. According to the headman from Kampung Pelanduk, the narrowing of the river due to the controlled water from the construction of watergates has resulted in poor coconut quality in terms of size and quality. Thus, in order to sustain their livelihoods, villagers opt for cultivation of crops that would generate better income compared to coconut in the area.

Literatures from Hon \& Shibata (2013), Olaniyi et al. (2013) and Tsuyuki et al. (2011) have described the shifting cultivation patterns in Sarawak which led to a shift to fruits and vegetable cultivation and a large-scale expansion of oil palm plantations due to the high yield capacity (Tsuyuki et al., 2011). With the expansion of oil palm plantations, the development had imposed environmental cost (GomezRoxas et al., 2005) where many forests being cleared and the living organisms, big and small, evacuated from the forests (Alam et al., 2015). The extensive use of agrochemicals such as fertilizers and pesticides potentially affect the aquatic life and drinkable water quality (Comte et al., 2012; Mercer et al., 2013). There has been a depletion of fishery resources due to freshwater pollution causing depletion of fish stock species despite recovery at varying degree (Chen et al., 2018; Kaur, 2017). As a result of this intensive agriculture activity, the fishermen at Sadong Jaya have to go deeper (more than five nautical miles away) in search for more fish resources. This situation is similar to that mentioned in Mazuki \& Man (2014).

On the other hand, the findings of the study show that a relatively high number of households surveyed ( 130 households or $53.5 \%$ ) have their family members out-migrate or disperse to cities or abroad for work. The outmigration is probably due to limited "glamorous" employment opportunities and low-income generating activities from farming sectors. This is consistent with the findings from Reza \& Alatas (2013) which has shown less interest among the youth to work in farming and fisheries sectors due to the uncomfortable and filthy environment induced by these sectors. This finding is supported by the study done by Rahman \& Akter (2014) which states that those with developed infrastructures is more likely to choose a non-agricultural livelihood. It is obvious that when more physical infrastructure is developed in Sadong Jaya particularly with the completion of Batang Sadong Bridge in 2016 and Batang Samarahan Bridge in 2018 respectively complemented by better road access, more communities members from Sadong Jaya started to have daily commute to their workplace outside the villages mainly to Kuching to seek for employment opportunities. The family members who stay back in the villages depend on remittance from these family members as their livelihoods though 
the remittance received by the riverine communities at Sadong Jaya are occasional or on a monthly basis in terms of money, food or necessity supply for the households. There are 25 (10.3\%) households depending on remittance as their main household income and 105 (43.2\%) households depending on remittance as their side household income. In addition, equipped with physical assets such as roads and bridges, family members have more market options to buy goods and to attain knowledge. This, in fact, would enhance capability to attain greater freedom to choose for livelihoods options (Bebbington, 1999; Sen, 1990) for a better quality of life.

As the livelihood strategies of the riverine communities are dependent on the available livelihood assets (Israr \& Khan, 2010), the livelihoods of the riverine communities are constantly changing. The accessibilities to basic facilities, job markets as well as markets for goods and services are facilitated by the provision of physical and human capital assets. These then help in sustaining the economic activities besides facilitating mobility among the riverine communities to access to better job opportunities outside their villages as well as access to the market to buy and sell goods and services to improve their well-being.

With the completion of Sadong Jaya Bridge in October 2016 and the Samarahan Bridge in June 2018, the riverine communities started using road transportation instead of river transportation. The accessibilities facilitated by bridges have drastically shortened the travel time from two hours to approximately 45 minutes from Sadong Jaya to Kuching. The shorter travelling time without being constraint by weather and tidal condition allow more riverine communities, especially the youths opting to find jobs in various fields in the city like Kuching compared to the limited job opportunities available in Sadong Jaya. The study of de Silva \& Kodithuwakku (2010) shows that economic diversification provides access of information, knowledge and experience. These can explain more diversification in terms of economic activities available in Sadong Jaya besides agricultural activities. An elderly local riverine community member from Sadong Jaya reiterated that,

"During the day, you will see farmers working at their farmlands; the village is very peaceful and quiet. But after five to six o'clock in the evening, motorbikes and cars start entering the village. The village younger generation now can travel out to cities to work. They go out very early in the morning and come back to the kampung (village) in the evening.", commented by Respondent 80 , a villager expressing the village scenario of a normal weekday in Sadong Jaya.

In another interview, a villager commented,

"Although they (her sons) travel a distance every day to Kuching, they save a lot of money as they don't need to pay (house) rental in Kuching. They get to eat home-cooked food and stay with me."

The benefit of having accessibility to markets with the construction of Batang Sadong and Batang Samarahan Bridges was highly commended by the riverine communities in Sadong Jaya. A married woman burger seller aged 39 from Kampung Tanjong Kelaso, an upper estuary of Sadong River informed that she managed to secure cheaper input materials for her burger business in the village by getting those materials from the hypermarkets in Kuching after the construction of Batang Sadong and Batang Samarahan Bridge.

"I normally will follow my husband to go to Kuching these days to buy the necessities as the price in Kuching or Kota Samarahan is much more competitive compared to the one I get it here (in village at Sadong Jaya). I managed to earn net income of RM30.00 daily by doing this small business of selling burger at least to earn some pocket money to support my family" (Respondent 121, Kampung Tanjong Kelaso, 2020).

Besides the upgraded transportation options, the drainage systems and watergates built in various areas in Sadong Jaya play an imperative role in protecting the farmlands and houses. The latter is due to the flood-prone geographical area of Sadong Jaya which experiences flood every year especially during monsoon seasons (between November to March), similar with the findings from Junaidi. Nurhamidah \& Daoed (2018). There are two types of flood identified in Sadong Jaya: man-made floods and natural floods. Man-made floods are caused by the inability of rainwater to be drained out of the village and overflowing of water from drainage system while natural floods are caused by king tides 
from the river. A watergate is used to control river and sea water flow into and out of the village. It helps to protect crops besides properties in the house from being destroyed or damaged by the flood. When there is rain, the gates are opened to allow excess water flowing out and when there are high tides, the gates are closed to prevent excess water from flowing in. Drainage systems are built from the river opening into the interior regions and farmlands of Sadong Jaya. During heavy rainfalls, the excess rainwater flows through the drainage system. With the construction of this physical watergates, it had reduced the damage caused by the natural disaster.

Better access to physical and human capitals is indeed considered as the most valued element in the society and can indicate the social status of the community (Kabir et al., 2012) due to income and employment opportunities from the non-farm economy (Rahman \& Akter, 2014). Past studies have indicated that the ability of communities to mitigate and prepare measures in facing vulnerabilities are related to their education level and income level (Nathan \& Mohamad, 2014; Samuel et al., 2017) as well as the type of non-farm activities indulged (Khatiwada et al., 2017). In other words, both physical and human capitals play a big role in determining the livelihood strategies adopted by the riverine communities. Besides that, other capital assets such as natural capital, social capital, financial capital are deemed important for future analysis as well.

\section{Conclusion}

Despite initial hypothesis of the study assumes that there is difference in the accessibility of various capital assets and vulnerabilities experienced among households located at different clusters (upper, middle and lower estuaries) among riverine communities in Sadong Jaya, the findings of this study shows otherwise. Instead, all households at Sadong Jaya are found to have similar traits and challenges despite being located at different geographical location of lower estuarine, middle estuarine and upper estuarine areas. The riverine communities in Sadong Jaya are all subject to vulnerabilities from flash flood occurrences irrespective of which specific location (lower, middle or upper estuarine areas) they are from though individual households might have different level of capital assets. Besides that, these riverine communities also face challenges of depleting natural resources and deteriorating environment as a result of agriculture and other development. The economic activities and livelihood strategies adopted by the villagers in Sadong Jaya are seen very much dependent on the physical and human capitals and complemented with other capital assets, particularly natural capital though the latter was not discussed extensively in this paper.

In spite of being exposed to various shocks and stresses due to its geographically disadvantaged location which is prone to flash floods and monsoon floods in particular, the riverine communities in Sadong Jaya seem to be able to cope and adapt well with environmental and socio-political changes. They are resilient in diversifying or expanding their livelihood portfolios by optimizing the use of physical and human capitals available as their strategies to sustain their livelihoods. In fact, the riverine communities in Sadong Jaya have benefited greatly particularly from the infrastructure development initiated by the government. Investment in physical capital, human capital as well as endowment of natural capital has enabled improved living standards among the riverine communities in Sadong Jaya. Better road connection for the riverine communities in Sadong Jaya as well as existence of Batang Sadong and Batang Samarahan bridges had undoubtedly improved accessibility of the local communities to jobs, goods and services markets. Besides, watergates built in the villages and its proximity area had reduced the vulnerability of the riverine communities to incur high cost imposed by the damages brought by the flash flood and monsoon flood particularly to their agriculture activities. Accessibility of the riverine communities to various capital assets has indeed empowered the riverine communities in Sadong Jaya to attain improved well-beings towards more sustainable livelihoods strategies by turning their capabilities into desirable livelihood outcomes.

In summary, this paper concludes that provision for and accessibility of basic physical assets, educational and training amenities by the riverine communities is crucially imperative as a policy recommendation to ensure that the riverine communities at Sadong Jaya are able to enhance their livelihoods strategies for uplifting their standards of living despite them suffering from depleting 
natural resources. The accessibility of tarred roads and bridges has enabled the riverine communities to improve their income generating capabilities as well as their accessibilities to marketplace and employment opportunities. At the same time, controlled sea water level from Watergate construction also modifies the soil structure and soil acidity level making coconut unsuitable to grow in the area. Nevertheless, the riverine communities in Sadong Jaya are able to adapt well by opting for alternative livelihood strategies.

The existence of education and training facilities in Sadong Jaya allowed the riverine communities, especially the youth to be equipped with necessary skills for better and broader scope of job opportunities. The adoption of a diversified income generating capabilities establish a resilient and better-off livelihood as more family members could expand their opportunities to engage in the workforce.

Comprehending the livelihood strategy of the riverine communities is important to identify the sustainability of the local communities at Sadong Jaya. The ever-changing dynamic conditions and the developing rate at Sadong Jaya, though relatively slow compared to other region, the findings of the study could act as inputs for policy makers for future planning and development in Sadong Jaya and even other riverine area to enhance the livelihoods of its people.

In few decades to come, the probability of on-farm job is more likely to decrease as more youths get educated and prefer to move out of the village to seek for alternative employment. Thus, migration to urban areas for education and job employment are more likely to happen more intensely in Sadong Jaya. With a declining manpower for farm activities in Sadong Jaya, food security might be a concern in the years to come. The adoption of technology in farming activities by the new educated young generation might help to sustain the food production activities if agropreneurship mindset is imparted to the youth population in Sadong Jaya.

As this paper is limited to only focus on the accessibility and the availability of physical and human capitals without engaging in-depth discussion on other capital assets, a more comprehensive and holistic analysis is thus suggested for future studies to evaluate livelihood vulnerabilities and the livelihood strategies carried out by the riverine communities in a more extensive manner. It is crucial for the authority and the community to offer initiatives in encouraging a better-balance development at Sadong Jaya in ensuring the sustainability of livelihoods by making the available capital assets as impetus of socio-economic development among riverine communities in particular.

\section{Acknowledgement}

The authors would like to thank Universiti Malaysia Sarawak (UNIMAS) for its support and the financial assistance through the Fundamental Research Grant Scheme, (F06/FRGS/1606/2017), for funding the research project and also the village headmen, villagers and the respective officers for providing rich information for this paper.

\section{References}

1. Abukari, Y. (2014). Livelihood strategies and the determinants of subjective wellbeing: A case study of subsistence farmers in the Northern region of Ghana. Retrieved from http://hdl.handle.net/123456789/7732

2. Adger, W. (2006). Vulnerability. Global Environmental Change, 16(3), 268-281.

3. Akther, S. Saha, S. G., Hossain, A. \& Islam, M. N. (2017). Livelihood strategies of riverine fishing communities of the river Padma near Rajshahi city corporation. International Journal of Fisheries and Aquatic Studies. 5(2), 195-199.

4. Alam, A. S. A.F., Er, A. C. \& Begum, H. 2015. Malaysian oil palm industry: Prospect and problem. Journal of Food, Agriculture \& Environment, 13(2), 143-148.

5. Ashley, C., \& Carney, D. (1999). Sustainable livelihoods: Lessons from early experience. Sustainable livelihoods, 1-64. 
6. Bhattacharjee, Mahua. (2010). Sustainable Livelihood: A study in rural and urban Assam. The Indian journal of social work, 71(3), 387-415.

7. Bebbington, A. (1999). Capitals and capabilities: A framework for analysing peasant viability, rural livelihoods and poverty. World Development, 27(12), 2021-2044.

8. Boncinelli, F. \& Casini, L. (2014). A comparison of the well-being of agricultural and non-agricultural households using a multicriterial approach. Social Indicators Research, 119 (1), 183-195.

9. Chambers, R. \& Conway, G. (1992). Sustainable Rural Livelihoods: Practical Concepts for the 21st Century. IDS Discussion Paper No. 296. Brighton: IDS.

10.Chen, Q., Shen, W. \& Yu, B. (2018). Assessing the vulnerability of marine fisheries in China: Towards an inter-provincial perspectivy. Sustainability, 10(4302), 1-14.

11.Chen, Y. C., Kao, S. P. \& Chiang, H. W. (2013). Defining an estuary using the Hilbert-Huang transform. Hydrological Sciences Journal, 58(4), 841-853.

12.Comte, I., Colin, F., Whalen, J. K., Grünberger, O. \& Caliman, J. (2001). Agricultural practices in oil palm plantations and their impact on hydrological changes, nutrient fluxes and water quality in Indonesia: A review. Advances in Agronomy, 116, 71-124.

13.Daw, Tim \& Adger, N. \& Brown, K. \& Badjeck, M.C. (2009). Climate change and capture fisheries. Climate change implications for fisheries and aquaculture. Overview of current scientific knowledge. FAO Fisheries and Aquaculture Technical Paper, 95-135.

14.De Silva, M. \& Kodithuwakku, S. (2010). Pluriactivity and socioeconomic success of rural households. Sri Lankan Journal of Agricultural Economics, 7, 85-108.

15.DeHaan, L. J. (2012). The livelihood approach: A critical exploration. Erdkunde, 66(4), 345-357.

16.Dlamini, C.S. (2014). African forests, people and climate change project: forest and climate changes policies, strategies and programmes in the SADC and COMESA Regions. African Forest Forum Working Paper Series, 2(17), 39.

17.Efobi, K. \& Anierobi, C. (2013). Impact of flooding on riverine communities: The experience of the omambala and other areas in Anambra Ssate, Nigeria. Journal of Economics and Sustainable Development, 4 (18), 58-63.

18.Elasha, B. O., Elhassan, N. G., Ahmed, H. \& Zakieldin, S. (2005). Sustainable livelihood approach for assessing community resilience to climate change: Case studies from Sudan. AIACC Working Paper No 17.

19.Elliott, M., Cutts, N.D., Trono, A. (2014). A typology of marine and estuarine hazards and risks as vectors of change: a review for vulnerable coasts and their management. Ocean. Coast Management, 98, 88-99.

20.Ellis, F. (1998). Household strategies and rural livelihood diversification. The Journal of Development Studies, 35, 1-38.

21.Ellis, F. (2000). The determinants of rural livelihood diversification in developing countries. Journal of Agricultural Economics, 51(2), 289-302.

22.Farzana, F.D., Rahman, A.S., Sultana, S., Raihan M.J., Haque, M.A., Waid, J.L., Chowdhury, N. \& Ahmed, T. (2017) Coping strategies related to food insecurity at the household level in Bangladesh. PLoS ONE,12(4), e0171411.

23.Gebru, G. W., Ichoku, H. E. \& Phil-eze, P. O. (2018). Determinant of livelihood diversification strategies in Eastern Tigray region of Ethiopia. Agriculture \& Food Security, 7(62).

24.Gomez-Roxas, P., Boniao, R. D., Burton, E. M., Gorospe-Villarino, A. \& Nacua, S. S. (2005). Community-based inventory and assessment of riverine and riparian ecosystems in the northeastern part of Mt. Malindang, Misamis Occidental, SEAMEO SEARCA, College, Laguna.

25. Haggblade, S. Hazell, P. \& Reardon, T. (2010). The rural non-farm economy: Prospects for growth and poverty reduction. World Development, 38(10), 1429-1441.

26. Hon, J. \& Shibata, S. (2013). A review on land use in the Malaysian state of Sarawak, Borneo and recommendations for wildlife conservation inside production forest environment. Borneo Journal of Resource Science and Technology, 3, 22-35.

27.Hussein, K. \& Nelson, J. (1998). Sustainable livelihoods and Livelihood Diversification, IDS Working Paper, Brighton: IDS. 
28.Israr, M. \& Khan, H. (2010). Availability and access to capitals of rural households in northern Pakistan. Sarhad Journal of Agriculture.,26, 443-450.

29.Junaidi, A., Nurhamidah, N. and Daoed, D. (2018). Future flood management strategies in Indonesia. MATEC Web of Conferences, 229(2), 01014.

30.Kabir, K. M. R., Adhikary, R. K., Hossain, M. B. \& Minar, M. H. (2012). Livelihood status of fishermen of the Old Brahmaputra River, Bangladesh. World Applied Sciences Journal, 16(6), 869-873.

31.Kamaruddin, R. \& Samsudin, S. (2014). The sustainable livelihoods index: A tool to assess the ability and preparedness of the rural poor in receiving entrepreneurial project. Journal of Social Economics Research, 1(6), 108-117.

32.Kaur, C. R. (2017). Fisheries resources management: Situational analysis and recommendations to address some of the major challenges in Malaysia. Sea View, 4, 1-5.

33.Khatiwada, S. P., Deng, W., Paudel, B., Khatiwada, J. R., Zhang, J. \& Su, Y. (2017). Household livelihood strategies and implication for poverty reduction in rural areas of central Nepal. Sustainability, 9(4), 612.

34.Khazanah Research Institute (2018). The state of households 2018: Different realities (3rd ed.). Kuala Lumpur, Malaysia: Khazanah Research Institute.

35.Krantz, L. (2001). The sustainable livelihood approach to poverty reduction. Stockholm.

36.Liu, Y., Huang, C., Wang, Q. \& Luan, J. (2017). Assessment of sustainable livelihood and geographic detection of settlement sites in ethnically contiguous poverty-stricken areas in the Aba Prefecture, China. International Journal of Geo-Information, 7(16), 1-18.

37.Luqmn, M., Yaseen, M, Nasir, S. \& Afzal, Y. (2018). Relationship between livelihood assets and strategies of small-scale farmers: Evidences from rain-fed areas of the Punjab, Pakistan. Journal of Advanced Agricultural Technologies, 5(1), 46-51.

38. Manlosa, A. O., Hanspach, J., Schultner, J., Dorresteijn, I. \& Fischer, J. (2019). Livelihood strategies, capital assets, and food security in rural Southwest Ethiopia. Food Security, 11, 167-181.

39.Manyena, S. (2006). The concept of resilience revisited. Disasters, 30(4), 434-450.

40.Masud, M. M., Kari, F., Yahaya, S. R. \& Al-Amin, A. Q. (2016). Livelihood assets and vulnerability context of marine park community development in Malaysia. Social Indicators Research, 125, 771792.

41.Mazuki, R. and Man, N. (2014). Acceptance of technology among Malaysian fishermen. Asian Social Sciencel, 10(16), 1-5.

42. Miththapala, S. (2013). Lagoons and estuaries. Coastal ecosystems series. IUCN Sri Lanka Country Office, Colombo.

43.Mercer, E. V., Mercer, T. G. and Sayok, A. K. (2013). Effects of forest conversions to oil palm plantations on freshwater macroinvertebrates: a case study from Sarawak, Malaysia. Journal of Land Use Science, 9(3), 260-277.

44.Myers, R. \& Hansen, C. P. (2019). Revisiting a theory of access: A review. Society \& Natural Resources, 33(2), 146-166.

45.Nathan, S. B. S. and Mohamad, M. R. (2014). Livelihood strategies and household income of a paddy farming community in Northwest Selangor, Malaysia. Journal of Emerging Economies and Islamic Research, 2(1).

46. Nelson, D. R, de Souza Filho, F. D. A, Finan, T. J, Ferreira, S. (2014). Trajectories of adaptation: A retrospectus for future dynamics. In Sakai, S. \& Umetsu, C. (Eds.), Social ecological systems in transition (pp. 121-136). Tokyo, Japan: Springer.

47. Olaniyi, A. O., Abdullah, A. M. Ramli, M. F. \& Sood, A. M. (2013). Agricultural land use in Malaysia: An historical overview and implications for food security. Bulgarian Journal of Agriculture Science, 19(1), 60-69.

48.Oriola, E. O. \& Chibuike, C. C. (2016). GIS for sustainable living in the riverine communities in edu local government area of Kwara state, Nigeria. GEOGRAFIA Online Malaysian Journal of Society and Space, 12 (1), 1-7.

49.Rahman, S. \& Akter, S. (2014). Determinants of livelihood choices: An empirical analysis from rural Bangladesh. Journal of South Asian Development, 9(3), 287-308. 
50.Reza, M. I. H. \& Alatas, S. M. (2013). A decision support system to deal with contemporary issues of climate change induced vulnerability and human security in Malaysia. Asian Journal of Environment and Disaster Management, 5 (3), 277-288.

51.Ribot, J. C. \& Peluso, N. L. (2003). A theory of access. Rural Sociology, 68(2), 153-181.

52.Sadong Jaya Sub-District Office. (2019). Population and household size. Sadong Jaya Sub-District Office.

53.Samuel, K. J., Ologunorisa, T. E., Samuel, Y. \& Kola-Olusanya, A. (2017). A post-disaster assessment of riverine communities impacted by a severe flooding event. Ghana Journal of Geography, 9(1), 17-41.

54.Schipper, L. E. F. \& Langston, L. (2015). A comparative overview of resilience measurement frameworks: Analysing indicators and approaches. London, United Kingdom: Overseas Development Institute.

55.Scoones, I. (1998). Sustainable rural livelihoods: A framework for analysis. DS Discussion Paper 72. University of Sussex, Brighton.

56.Sen, A. (1990). Development as capability expansion. In K. Griffin \& J Knights (Eds). Human development and international development strategy for the 1990s. London: MacMillan.

57.Sharma, V., Reddy, B. \& Sahu, N. (2014). Sustainable rural livelihoods approach for climate change adaptation in Western Odisha, Eastern India. Development in Practice, 24(4), 591-604.

58.Tsuyuki, S., Goh, M., Teo, S., Kamlun, K., \& Phua, M. (2011). Monitoring deforestation in Sarawak, Malaysia using multitemporal Landsat data. Kanto Forest Research Journal, 62, 87-90.

59.Twigg J. (2001). Sustainable Livelihoods and Vulnerability to Disasters. London: Benfield Greig Hazard Research Centre Working Paper 2

60.USAID. (2018). Guide for planning long-term impact evaluations (LTIEs): Utilizing the expertise of the Expanding the Reach of Impact Evaluation (ERIE) program consortium. United States Agency for International Development. Retrieved from https://pdf.usaid.gov/pdf_docs/PA00T9HJ.pdf

61.UNDP. (2017). Guidance Note: Application of the sustainable livelihoods framework in development projects. United Nations Development Programme. Retrieved from www.undp.org

62.WCED. (1987). Our Common Future. World Commission on Environment and Development. Oxford University Press, London.

63.Xing, C. (2016). Human Capital and Urbanization in the People's Republic of China. ADBI Working Paper No. 603.

64.Yassin, S.M., Shaffril, H. A.M., Hamazah, A. \& Idris, K. (2018). Assessing rural youth sustainable livelihood in Malaysia. Pertanika Journal of Social Sciences \& Humanities, 26 (T), 1-18.

65.Yuerlita, Perret. S. R. \& Shivakoli, G. P. (2013). Fishing farmers or farming fishers? Fishing typology of inland small-scale fishing households and fisheries management in Singkarak Lake, West Sumatra, Indonesia. Environmental Management, 52, 85-98. 